\title{
Financial performance measurement with the use of financial ratios: case of Mongolian companies
}

\author{
B. BATCHIMEG \\ University of Debrecen, Faculty of Economics and Business, Department of Finance, \\ bayaraa.batchimeg@econ.unideb.hu
}

Abstract. The aim of this paper is to examine the efficiency of Mongolian 100 public companies listed on Mongolian Stock Exchange (MSE) which are divided into 6 major sectors. This study conducts the performance of companies in terms of profitability by using three different output variables i.e., revenue, pretax profit and ROA (Return on Assets). In the beginning of this research, nine variables which are connected with profitability are chosen as output variables, while 24 variables expressing growth, financial structure, solvency, and turnover together with some fundamental financial data are chosen as input variables. 10 variables out of 24 input variables, which determine the financial structure, solvency, and profitability, are chosen as input variables based on the calculation of stepwise regression analysis. Stepwise regression, multi co-linearity analysis are made by SPSS and DEA (Data envelopment analysis) is evaluated by benchmarking package in $R$ excel statistical program covering the period of 2012-2015. This paper uses the input-oriented version of DEA based on financial ratios and some crucial components of a financial statement. The results of DEA show that food and grocery sector was the most efficient, and mining sector was at the second place by its efficiency, while agriculture and service sector were the worse than other sectors.

\section{Introduction}

For every company, monitoring efficiency is one of the key activities. Efficiency measurement methods can be divided into three main categories: ratio indicators, parametric and nonparametric methods [16]. DEA is a nonparametric method, which has the origin in production theory as a means to evaluate production efficiency [17].

Financial performance measurement by using DEA was examined by plenty of researchers. For example, Kristina et al. (2005) did research about using DEA models to measure efficiency, Luo (2001) evaluated the profitability efficiency of large banks, and Liu (2011) Performance measurement of Taiwan financial holding companies etc.

Different accounting and financial indicators are the most appropriate for evaluation and comparison of corporate performance [7]. Users of DEA often employ ratios rather than absolute numbers as indicators of outputs and inputs in DEA [9].

Many researchers analyzed DEA with the use of financial ratios, for instance, Necmi (2010) examined Chinese bank efficiency with financial ratios, Gianpaolo (2013) examined the research "Using DEA and financial ratings for credit risk evaluation", George et al. (2011) evaluated the 
performance of 23 Greek manufacturing sectors with the use of financial ratios, Fenyves (2015) evaluated financial performance of agricultural enterprises with the DEA method, Jose et al. (2010) evaluated port efficiency of 11 Chinese ports.

Likewise, there are also some researches about financial performance with financial ratios using other methods than DEA such as: Sanghani (2016) measured financial performance through ratio analysis using chi-square test, and Hornungova et al. (2016) evaluated financial performance evaluation of the Czech agricultural companies with factor analysis.

George (2011) measured the performance of 23 Greek manufacturing sectors providing empirical evidence of the influence of performance evaluation when different financial ratios in different sectors are adopted, which was similar to my research. But there is not any research analyzed financial performance measurement in the case of Mongolian companies. The main purpose of this research is to rank Mongolian business sectors by their efficiency, to do so financial efficiencies were calculated which expressed by 3 different indicators: ROA, pretax profit, and revenue. Output variables are determined by growth, financial structure and profitability ratios over the period of 2012-2015 in Mongolian public companies. However, 227 companies are listed on MSE, companies are deducted from research due to bankruptcy, no annual reports, and zero values in financial data which used for research. Therefore, 100 companies' financial statements are used in the research regarding to the data availability.

In order to present investors with a concise view of the Mongolian economy, Mongolian businesses are classified into 20 business sectors on MSE's website. For this study, companies are divided into 6 sectors, i.e., food and grocery, production of construction, mining, agriculture, service, and miscellaneous.

Objectives of the study are to answer the questions below:

- To conduct what ratios and financial data can determine the corporate efficiency.

- To examine if there is any statistically significant difference in financial efficiency among the 6 sectors in Mongolia.

- What sector are the most efficient/the worst in efficiency among Mongolian 6 sectors?

The rest of this paper is organized as follows: Section two reviews the literature about financial performance, and data envelopment analysis (DEA). Section three provides data and variables, and the methodology of this study. Section four consists of empirical results and discussion. Finally, conclusions are drawn in section five.

\section{Literature review}

Corporate performance is the measurement for what had been achieved by a company. Relative performance evaluations or benchmarking is the systematic comparison of the performance of one firm against other DMUs (decision-making units) [15]. DMUs can be firms, organizations, divisions, industries, projects or individuals. DEA is a non-parametric approach to weigh the inputs/outputs and measure the relative efficiency of DMUs [3]. 
An important feature is DEA is able to deal with multiple outputs and multiple inputs. The problem then becomes either maximize weighted output with a weighted input equal to one or minimize weighted input with weighted output equal to one [9]. When we use DEA method, both quantitative and qualitative characteristics are possible to use, and the method gives us the opportunity to measure corporate performance in a proper and complex way [7].

The single most widely used approach to measuring the degree of efficiency in a general multiinput and multi-output setting is the strategy suggested by Debreu and Farrell, usually referred to simply as Farrell efficiency (input efficiency/technical efficiency) [15]. Being technically efficient means to minimize inputs at a given level of outputs, or maximize outputs at a given level of inputs [16]. Input efficiency takes the value between $0-1.0$, for example, a value of 0.6 obtained by the input-oriented method means that we could still produce the same output if we decreased the inputs by $40 \%$.

Likewise, output efficiency means the given enterprise, compared with effective firms, uses much more input to produce the particular output. For example, a value of 1.4 obtained by the output-oriented model means that the given company, compared to effective firms, could increase its output by $40 \%$ without involving any additional input source [15]. Both input efficiency and output efficiency take the value 1.0 for efficient companies.

Parametric methods of efficiency measurement include Stochastic Frontier Approach (SFA), which measures economic efficiency. Being economically efficient means to choose a certain volume and structure of inputs and outputs in order to minimize cost or maximize profit. Technical efficiency only requires input and output data, but economic efficiency requires price data as well [16].

DEA differs by its model supporting scale assumptions: constant return to scale (CRS) and variable return to scale (VRS) which consists of increasing (IRS) and decreasing return to scale (DRS) [7]. If any possible production combination can arbitrarily be scaled up or down, we have the assumption of CRS. Decreasing returns to scale means that the output will tend to increase less than the input such that it will be possible to scale down but not up. Increasing returns to scale mean that the output will tend to grow faster than the input. One reason for this is that a larger scale implies more experience, more efficient processes and a better ability to utilize specialization possibilities [15]. Users of DEA often employ ratios rather than absolute numbers as indicators of outputs and inputs in DEA. If the ratio form of DEA is used, then it is essential that the VRS form of the DEA model should be specified, since the CRS model is technically incorrect [9].

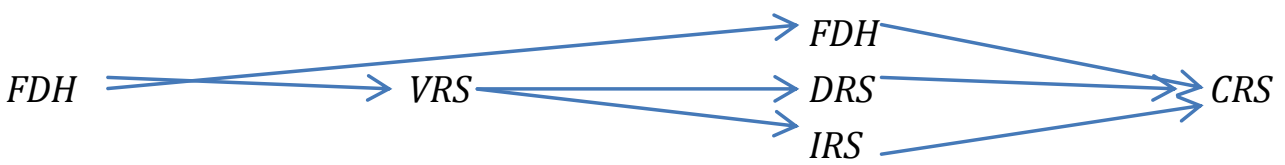

Figure 1. Technology sets of DEA

FDH is the smallest technology set. The FDH (free disposability hull) model usually gives the best values, but it is not easy to satisfy its conditions. FRH (free replicability hull) is a modified version of FDH. VRS (variable returns to scale) gives higher efficiency scores and higher cost 
norms. Choosing between DRS (decreasing returns to scale) and IRS (increasing returns to scale) depends on the firm's production function [15].

Scale efficiency (SE) ratio shows how close the current size of a company is to the optimal size [7]. The larger the SE, the closer the firm is to optimal scale [15]. SE is the ability to get the most outputs per input, and it is measured as the ratio of CRS-based efficiency and VRS-based efficiency [15].

\section{Data, variables and research methodology}

Financial statements used as data are obtained from MSE's website. Mongolian Stock Exchanged was established with connection with the transition period from a centrally planned economy to a market economy in Mongolia on 18 January 1991. Mongol Shiltgeen Company became a public company by issuing 10 million shares, and 1 million shares of them offered to the public and registered at Mongolian Stock Exchange on 25 May, which was the first IPO launched in Mongolia [2]. According to the Mongolian law of auditing, public companies' financial statement must be audited before stockholders' meeting. It increases the reliability of data compared with non-public companies' financial statements [1]. This study used the benchmarking package of $\mathrm{R}$ statistical program for 100 Mongolian public companies' financial statements with the duration of 4 years (400 the observations).

\subsection{Performance Variables}

The choice of the inputs and outputs is very crucial for the relative efficiencies to be useful in arriving at meaningful conclusions [8]. It is often necessary to use ratios rather than absolute numbers as inputs and outputs in data envelopment analysis. In this study, 9 output variables and 24 input variables are selected to be examined. Each output variables are analyzed by linear regression in SPSS separately, and three variables which had the highest value in adjusted $\mathrm{R}$ square are chosen for further research as output variables. Output variables (ROA, pretax profit, and revenue) are calculated separately, and their results are examined to determine corporate efficiency for Mongolian companies. Stepwise regression and multi co-linearity analyses are done by SPSS software package to choose the input and output variables. According to stepwise regression analysis result, 14 inputs out of total 24 are correlated with 3 chosen output variables, but 4 variables which have VIF higher than 2.5 are deducted from the further research, due to the multi co-linearity.

\subsection{Output variables}

Return on Assets (ROA): dividing net income by total assets.

Revenue: subtracting sales returns and allowances from total revenue.

Pretax profit: subtracting operational and non-operational expenses (loses) from profit margin.

\subsection{Input variables}


Cost to revenue ratio: dividing total costs by revenue.

Return on costs: net profit divided by total costs.

Current assets to total assets ratio: current assets divided by total assets.

Total liabilities to total assets ratio: total liabilities divided by total assets.

Operating profit to fixed assets ratio: operating profit divided by fixed assets.

Operating profit to total assets ratio: operating profit divided by total assets.

Receivable turnover: revenue divided by the amount of receivable.

Operational expenses: the sum of marketing costs and managerial costs.

Total equity

Costs of goods sold

\begin{tabular}{|c|c|c|c|c|}
\hline Segments & Ratios & ROA & $\begin{array}{c}\text { Pretax } \\
\text { profit }\end{array}$ & Revenue \\
\hline \multirow{2}{*}{ Profitability } & Cost to revenue ratio & & & \\
\hline & Return on costs & & & \\
\hline \multirow{2}{*}{$\begin{array}{l}\text { Financial } \\
\text { structure }\end{array}$} & Current assets to total assets & & & \\
\hline & Total liabilities to total assets & & Collinear & Collinear \\
\hline \multirow{3}{*}{ Turnover } & Operating profit to fixed assets & & & \\
\hline & Operating profit to total assets & & & \\
\hline & Receivable turnover & & & Collinear \\
\hline \multirow{3}{*}{ Financial data } & Operational expenses & & & \\
\hline & Total equity & & & Collinear \\
\hline & Costs of goods sold & & Collinear & \\
\hline \multicolumn{2}{|r|}{ R square } & 0.816 & 0.570 & 0.976 \\
\hline \multicolumn{2}{|r|}{ Adjusted R square } & 0.813 & 0.563 & 0.976 \\
\hline
\end{tabular}

Table1. Variables chosen for the research

Table 1 shows the stepwise regression results which are used to choose input variables out of total 24. Shaded variables are chosen as inputs; however, some of the variables from stepwise regression were deducted from further research due to multi co-linearity and as written colinear in the cells.

\begin{tabular}{|l|r|r|r|r|}
\hline & Minimum & \multicolumn{1}{|c|}{ Maximum } & \multicolumn{1}{|c|}{ Mean } & Std. Deviation \\
\hline ROA & -1.9 & 0.5 & 0.0 & 0.1 \\
\hline Pretax profit & -14251672.0 & 106699207.6 & 1721945.2 & 9390835.8 \\
\hline Revenue & 0.0 & 255895259.8 & 14083072.9 & 38462770.7 \\
\hline Cost to revenue ratio & -19.8 & 2.5 & -0.1 & 1.1 \\
\hline Return on costs & -4.4 & 55.8 & 2.2 & 6.5 \\
\hline Current assets to total assets & 0.0 & 1.0 & 0.3 & 0.2 \\
\hline
\end{tabular}




\begin{tabular}{|l|r|r|r|r|}
\hline Total liabilities to total assets & 0.0 & 4.9 & 0.4 & 0.4 \\
\hline Operating profit to fixed assets & -9.4 & 11.7 & 0.0 & 1.2 \\
\hline Operating profit to total assets & -2.1 & 0.7 & 0.0 & 0.2 \\
\hline Receivable turnover & 0.0 & 7125.6 & 104.0 & 604.6 \\
\hline Operational expenses & 0.0 & 64519117.9 & 2635235.3 & 7941265.7 \\
\hline Total equity & -19576550.5 & 337586370.9 & 14201800.0 & 37353496.7 \\
\hline Costs of goods sold & 0.0 & 191124097.6 & 9459880.4 & 25434959.9 \\
\hline
\end{tabular}

Table 2: Descriptive statistics of input and output variables

The table 2 details the descriptive statistics regarding to the inputs and outputs used in DEA methodology. From the result, we can observe considerable high values of standard deviations among the companies, which indicate that the relatively big and small companies are chosen as data.

\section{Analysis and results}

In the scope of this research, Mongolian 100 public companies' performance measurement was evaluated by DEA in R excel statistical program based on their 4 years financial reports from the Mongolian Stock Exchange website.

As it is shown in figure 2, the input efficiency result of 100 Mongolian public companies; ROA used as an output variable, while cost to revenue ratio, return on costs, total liabilities to total assets, operating profit to fixed assets, and operating profit to total assets are chosen as input variables. Only 5 companies out of 100 companies were efficient throughout the research period, while 47 companies worked inefficiently for 4 years period.

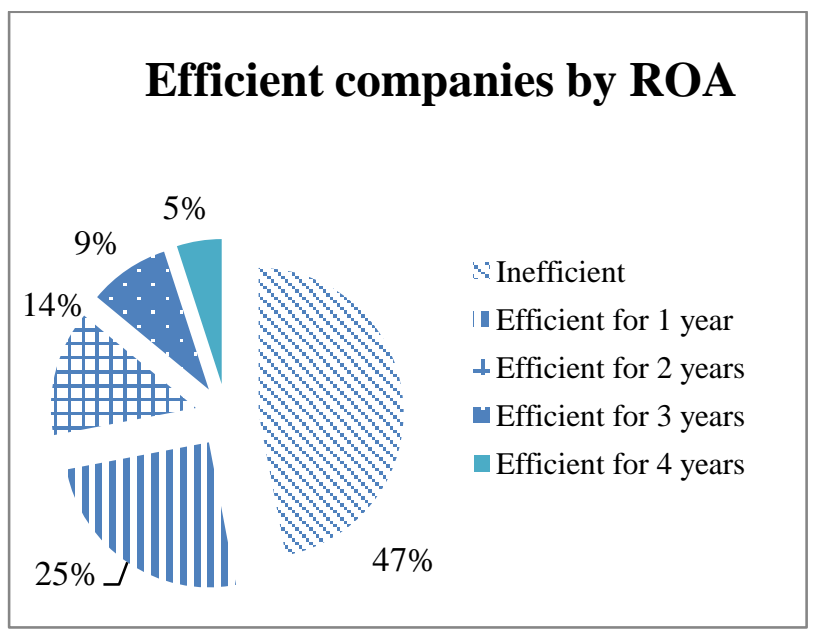

\begin{tabular}{|l|c|c|c|l|}
\hline \multicolumn{5}{|c|}{ Descriptive Statistics- ROA } \\
\hline Years & Min & Max & Mean & St.Dev \\
\hline 2012 & 0.36 & 1.00 & 0.77 & 0.17 \\
\hline 2013 & 0.46 & 1.00 & 0.84 & 0.14 \\
\hline 2014 & 0.43 & 1.00 & 0.81 & 0.15 \\
\hline 2015 & 0.40 & 1.00 & 0.83 & 0.14 \\
\hline Average & 0.41 & 1.00 & 0.81 & \\
\hline
\end{tabular}

Figure 2. The percentage of efficient companies based on the ROA output variable throughout the research period

Figure 3 details the number of efficient companies throughout the research period. Pretax profit used as an output variable, while current assets to total assets, operating profit to fixed assets, receivable turnover, operational expenses, and total equity are used as input variables. 7 companies were efficient throughout the period, but 48 companies worked inefficiently for 4 
years period. We can see from the mean efficiency score from the table that efficiency based on ROA is higher, which had the yearly average mean of efficiency score 0.81 , than that of pretax profit, which had 0.59 mean.

\begin{tabular}{|l|c|c|r|r|}
\hline \multicolumn{5}{|c|}{ Descriptive Statistics- Pretax profit } \\
\hline Years & Min & Max & Mean & St. Dev \\
\hline 2012 & 0.11 & 1.00 & 0.59 & 0.27 \\
\hline 2013 & 0.09 & 1.00 & 0.52 & 0.31 \\
\hline 2014 & 0.23 & 1.00 & 0.64 & 0.27 \\
\hline 2015 & 0.19 & 1.00 & 0.61 & 0.27 \\
\hline Average & 0.15 & 1.00 & 0.59 & \\
\hline
\end{tabular}

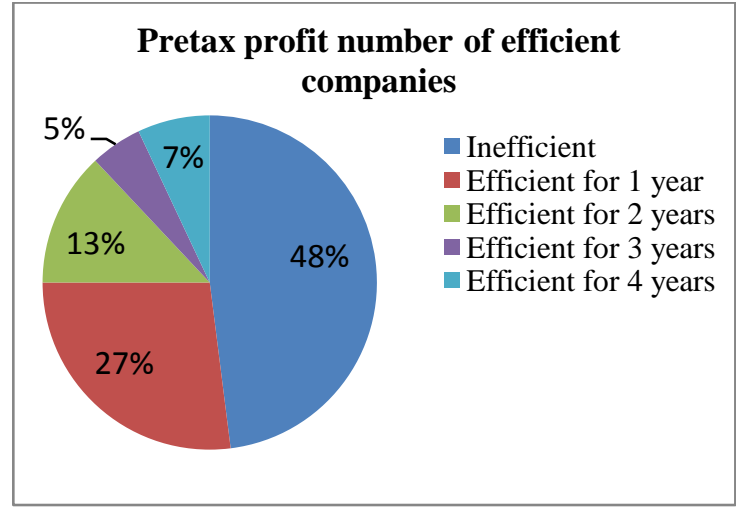

Figure 3. The percentage of efficient companies based on the pretax profit output variable throughout the research period

\section{Efficient companies by revenue}

- Inefficient

Efficient for 1 year

Efficient for 2 years

Efficient for 3 years

Efficient for 4 years

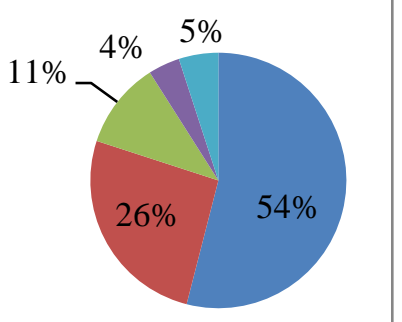

\begin{tabular}{|l|l|l|r|r|}
\hline \multicolumn{5}{|c|}{ Descriptive Statistics - Revenue } \\
\hline & Min & Max & \multicolumn{1}{c|}{ Mean } & Std. Dev \\
\hline 2012 & 0.04 & 1.00 & 0.61 & 0.26 \\
\hline 2013 & 0.05 & 1.00 & 0.47 & 0.31 \\
\hline 2014 & 0.04 & 1.00 & 0.63 & 0.30 \\
\hline 2015 & 0.12 & 1.00 & 0.70 & 0.26 \\
\hline Average & 0.06 & 1.00 & 0.60 & \\
\hline
\end{tabular}

Figure 4. The percentage of efficient companies based on the revenue output variable throughout the research period 
Figure 4 represents the input efficiency VRS result of 100 Mongolian public companies. Revenue used as an output variable, while operating profit to fixed assets, operational expenses, and Costs of goods sold are chosen as input variables. Like the results of ROA input efficiency, 5 companies worked efficiently throughout the research period, but 54 companies worked inefficiently for 4 years period. From the yearly descriptive statistics, we can see that compared with other 2 alternatives, input based on Revenue has the minimum efficiency score which is 0.06 , while input efficiency by ROA results in 0.41 (minimum).

\begin{tabular}{|c|c|c|c|}
\hline \multirow{2}{*}{$\begin{array}{l}\text { Efficiency } \\
\text { range }\end{array}$} & ROA & Pretax Profit & Revenue \\
\hline & Mean efficiency 59.4 & Mean efficiency 41.4 & Mean efficiency 61.3 \\
\hline $0.1-0.2$ & 4 & 32 & 2 \\
\hline $0.2-0.3$ & 11 & 17 & 12 \\
\hline $0.3-0.4$ & 20 & 17 & 10 \\
\hline $0.4-0.5$ & 10 & 7 & 9 \\
\hline $0.5-0.6$ & 12 & 5 & 16 \\
\hline $0.6-0.7$ & 7 & 3 & 17 \\
\hline $0.7-0.8$ & 8 & 2 & 10 \\
\hline $0.8-0.9$ & 5 & 0 & 5 \\
\hline $0.9-1.0$ & 3 & 0 & 3 \\
\hline 1.0 & 20 & 17 & 16 \\
\hline Minimum & 0.12 & 0.11 & 0.10 \\
\hline $1^{\text {st }}$ quartile & 0.34 & 0.18 & 0.41 \\
\hline Median & 0.55 & 0.30 & 0.60 \\
\hline Mean & 0.59 & 0.41 & 0.61 \\
\hline $3^{\text {rd }}$ quartile & 0.85 & 0.53 & 0.76 \\
\hline Maximum & 1.00 & 1.00 & 1.00 \\
\hline
\end{tabular}

Table 3: Input efficiency scores for DMUs (Calculated from the average of 4 years)

As it is shown in table 3 first row, the 20 out of 100 (20\%) companies proved to be efficient by ROA ratio, and the mean efficiency score was $59.4 \%$. However, only 16 companies $(16 \%)$ were efficient by revenue, the mean efficiency (61.3\%) was the highest compared with other 2 alternatives. Lowest efficiency scores were $0.12,0.11$ and 0.1 , which were similar to every output. We can conclude that input efficiency calculated by Revenue (61.3\%) is much higher than that of pretax profit (41.4\%), which means operational costs and costs of goods sold are relatively high. 


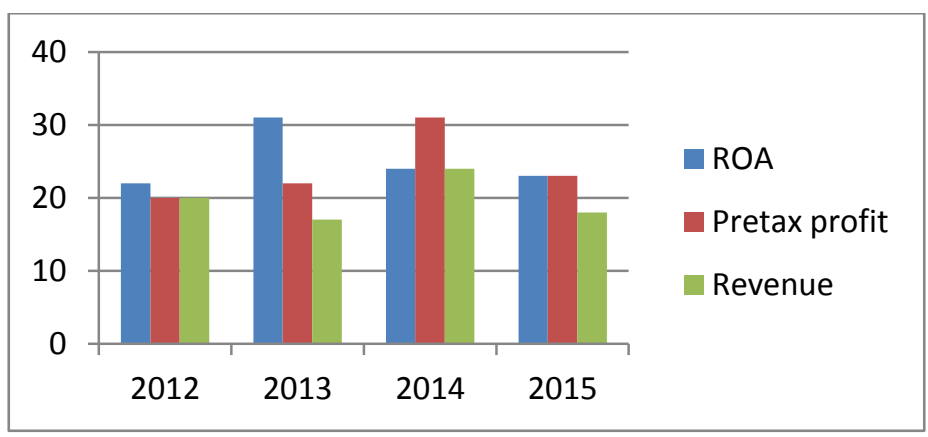

Figure 5: The number of efficient companies by year

By looking at figure 5, we notice that the number of efficient companies was similar in 2012 for all alternatives; however, the number of efficient companies by ROA skyrocketed in 2013, efficiency by pretax profit boosted in 2014 .

\begin{tabular}{|c|c|c|c|}
\hline Efficiency range & ROA & Pretax Profit & Revenue \\
\hline 1.0 & 12 & 8 & 15 \\
\hline $1.0-1.1$ & 1 & 0 & 2 \\
\hline $1.1-1.2$ & 0 & 0 & 4 \\
\hline $1.2-1.3$ & 2 & 0 & 15 \\
\hline $1.3-1.5$ & 2 & 0 & 22 \\
\hline $1.5-2.0$ & 7 & 1 & 22 \\
\hline $2.0-5.0$ & 12 & 14 & 8 \\
\hline $5.0-10$ & 7 & 10 & 4 \\
\hline $10-100$ & 11 & 5 & Inf \\
\hline $100-$-inf & 1 & Inf & 1.201 \\
\hline Minimum & Inf & Inf & 1.589 \\
\hline 1 st quartile & Inf & 1 & Inf \\
\hline Median & 1 & Inf & 2.5 \\
\hline Mean & Inf & 8.1 & 48.7 \\
\hline $3^{\text {rd }}$ quartile & 2.8 & 192.4 & 3 \\
\hline Maximum & 105.2 & 18 & \\
\hline
\end{tabular}

Table 4: Output efficiency scores for DMUs (Calculated from the average of 4 years)

The output efficiency is calculated in table 4 above, which shows that without changing the amount of input how much amount of output is able to be increased. The efficiency rate 1 shows the most efficient company, while the greater scores show how much output can be increased using the same amount of input. We can conclude from the table 4 that only 8 companies are efficient and the worst company's efficiency score was 192.4 for output efficiency calculated by using pretax profit, but the 
number of output efficient companies was 15 for revenue based output efficiency which had the highest number and resulted in 48.72 (maximum). The mean of efficiency is inefficient for every case.

\begin{tabular}{|c|c|c|c|c|c|c|c|c|c|c|}
\hline \multirow[t]{2}{*}{ Sectors } & 畩 & 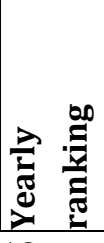 & 竞 & 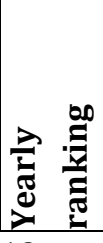 & 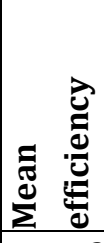 & 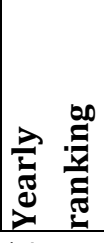 & 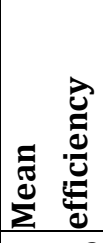 & 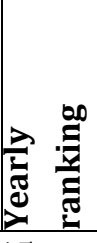 & \multirow[t]{2}{*}{ 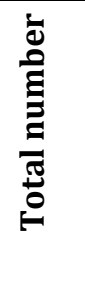 } & \multirow[t]{2}{*}{ 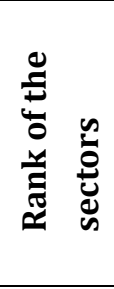 } \\
\hline & \multicolumn{2}{|c|}{2012} & \multicolumn{2}{|c|}{2013} & \multicolumn{2}{|c|}{2014} & \multicolumn{2}{|c|}{2015} & & \\
\hline Food and grocery & 99.1 & 3 & 96.3 & 4 & 100 & 1 & 95.0 & 3 & 11 & 2 \\
\hline Service sector & 86.5 & 6 & 95.2 & 5 & 88.6 & 6 & 94.2 & 4 & 21 & 6 \\
\hline Mining & 100 & 1 & 99.8 & 1 & 99.8 & 2 & 99.9 & 1 & 5 & 1 \\
\hline Agriculture & 95.0 & 4 & 97.7 & 3 & 93.9 & 5 & 90.8 & 6 & 18 & 5 \\
\hline $\begin{array}{l}\text { Production of } \\
\text { construction }\end{array}$ & 99.9 & 2 & 99.6 & 2 & 98.9 & 3 & 93.7 & 5 & 12 & 3 \\
\hline Miscellaneous & 92.7 & 5 & 86.2 & 6 & 96.2 & 4 & 97.2 & 2 & 17 & 4 \\
\hline
\end{tabular}

Table 5: Input efficiency based on ROA by sectors

From the table 5 input efficiency results based on ROA, we can assume that mining sector was the most efficient throughout the years of this research. The result was not surprising, because the mean of cost to revenue ratio was the second lowest, after construction sector. On the one hand, total liabilities to total assets ratio was the second highest 0.61 , which showed debt management of the sector had been efficient. On the other hand, liabilities to total assets ratio was the lowest 0.29 for the service sector, which was the less efficient sector. However, it is noteworthy that the number of companies in one sector was not equal to each other. The number of companies in a sector was: Food and grocery 11, service sector 36 , miscellaneous 17, mining 10, agriculture 14, production of construction 12 .

\begin{tabular}{|c|c|c|c|c|c|c|c|c|c|c|}
\hline \multirow[t]{2}{*}{ Sectors } & 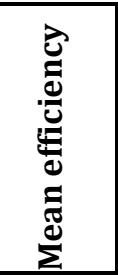 & 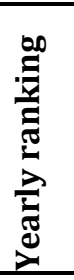 & 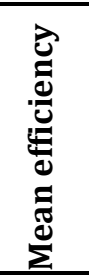 & 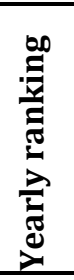 & 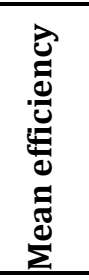 & 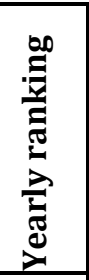 & 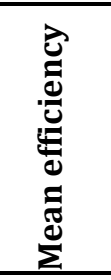 & 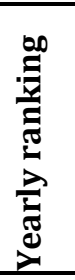 & \multirow[t]{2}{*}{ 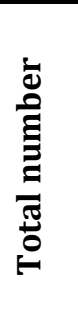 } & \multirow[t]{2}{*}{ 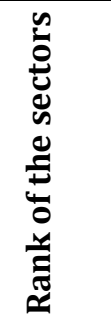 } \\
\hline & \multicolumn{2}{|c|}{2012} & \multicolumn{2}{|c|}{2013} & \multicolumn{2}{|c|}{2014} & \multicolumn{2}{|c|}{2015} & & \\
\hline Food and grocery & 100.0 & 1 & 98.7 & 1 & 99.5 & 1 & 100.0 & 1 & 4 & 1 \\
\hline Service sector & 84.1 & 6 & 85.6 & 5 & 84.3 & 6 & 88.1 & 6 & 23 & 5 \\
\hline Mining & 88.3 & 5 & 81.0 & 6 & 95.0 & 2 & 97.3 & 2 & 15 & 3 \\
\hline Agriculture & 94.8 & 2 & 87.0 & 4 & 87.1 & 5 & 89.5 & 4 & 18 & 4 \\
\hline Production of construction & 93.4 & 4 & 93.1 & 3 & 93.2 & 3 & 88.6 & 5 & 15 & 3 \\
\hline Miscellaneous & 93.7 & 3 & 90.1 & 3 & 87.9 & 4 & 92.7 & 3 & 13 & 2 \\
\hline
\end{tabular}

Table 6 describes the food and grocery sector was the most efficient sector throughout the years based on the input efficiency results. The sector ranked $1^{\text {st }}$ by its current assets to total assets ratio 0.54 , and also the sector had the highest score in operation revenue to fixed assets ratio 0.33 . In contrast, service 
sector which was the less efficient than other sectors had the lowest score for those ratios $0.32,0.27$, respectively. Like the efficiency result of ROA, the service sector was the less efficient also for pretax profit results. But the mining sector which was the most efficient in ROA result was less efficient and ranked in $3^{\text {rd }}$ place.

\begin{tabular}{|c|c|c|c|c|c|c|c|c|c|c|}
\hline \multirow[t]{2}{*}{ Sectors } & 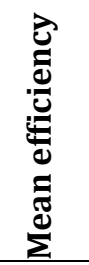 & 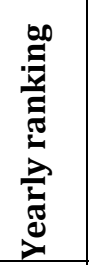 & 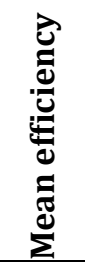 & 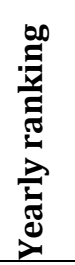 & 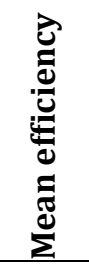 & 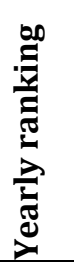 & 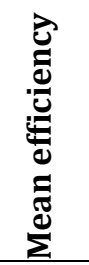 & 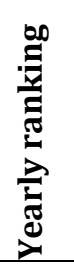 & \multirow[t]{2}{*}{ 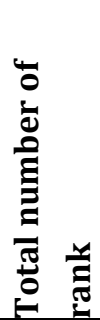 } & \multirow[t]{2}{*}{ 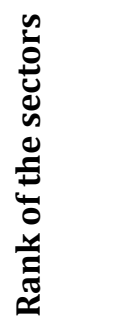 } \\
\hline & \multicolumn{2}{|c|}{2012} & \multicolumn{2}{|c|}{2013} & \multicolumn{2}{|c|}{2014} & \multicolumn{2}{|c|}{2015} & & \\
\hline Food and grocery & 97.4 & 1 & 97.5 & 1 & 97.8 & 2 & 97.5 & 2 & 6 & 1 \\
\hline Service sector & 79.5 & 5 & 82.0 & 4 & 88.8 & 4 & 84.0 & 4 & 17 & 4 \\
\hline Mining & 95.4 & 2 & 90.0 & 3 & 99.0 & 1 & 99.2 & 1 & 7 & 2 \\
\hline Agriculture & 92.6 & 4 & 62.0 & 6 & 70.7 & 6 & 77.2 & 6 & 22 & 6 \\
\hline Production of construction & 95.1 & 3 & 96.0 & 2 & 93.5 & 3 & 89.0 & 3 & 11 & 3 \\
\hline Miscellaneous & 74.6 & 6 & 69.8 & 5 & 77.2 & 5 & 78.8 & 5 & 21 & 5 \\
\hline
\end{tabular}

Table 7: Input efficiency based on revenue by sectors

As we can see from the table 7, food and grocery sector was the most efficient by the result of revenue and pretax profit. Operational expenses to revenue ratio were $13.78 \%$ for food and grocery sector, while agricultural sector, which was the least efficient sector, had that of $47.93 \%$.

\begin{tabular}{|c|c|c|c|c|c|}
\hline Sectors & ROA & Pretax profit & Revenue & Total rank & Rank \\
\hline Food and grocery & 2 & 1 & 1 & 4 & $\mathbf{1}$ \\
\hline Service sector & 6 & 5 & 4 & 15 & $\mathbf{5}$ \\
\hline Miscellaneous & 4 & 2 & 5 & 11 & $\mathbf{4}$ \\
\hline Mining & 1 & 3 & 2 & 6 & $\mathbf{2}$ \\
\hline Agriculture & 5 & 4 & 6 & 15 & $\mathbf{5}$ \\
\hline Production of construction & 3 & 3 & 3 & 9 & $\mathbf{3}$ \\
\hline
\end{tabular}

Table 8: Sector ranking based on the input efficiency results

From the table 8, we can conclude that food and grocery sector and mining sector are the most efficient sectors in Mongolia, while service sector and agriculture are the less efficient.

\section{Conclusion}

The aim of this study is to measure the performance by using three different outputs (ROA, pretax profit, and revenue), and evaluate if there is any difference exists related to its sector. The paper uses DEA input efficiency-variable return to scales (VRS) and output efficiency to examine the financial performance determinants for Mongolian 6 sectors. Multi co-linearity and stepwise regression analysis are used to decide input and output variables. ROA, pretax profit, and revenue are chosen as output variables. Out of 24 independent variables, financial structure, liquidity and profitability related 10 ratios determine efficiency. Each sector's input efficiency was calculated for 4 years and 
ranked separately to determine the most efficient sector and the less efficient sector. From the calculation, food and grocery sector was the most efficient sector, however, efficiency result based on ROA showed mining sector the most efficient and food and grocery ranked $2^{\text {nd }}$ place. The worst sector by input efficiency was agriculture and service sectors which ranked $5^{\text {th }}$ both.

Based on the performance measurement on the 100 public companies' 4 years financial reports, mean efficiency in every year fluctuated greatly. It shows us the data reliability and the current economic situation has affected the results.

Limitations and Recommendations

This research uses only four years' financial statements which are a relatively short-time period and uses only public companies' statements. Therefore, a further researcher may extend the present study by more years and by non-public companies' statements.

\section{References}

[1] legalinfo.mn. (2015, 06 19). Retrieved 01 16, 2017, from legalinfo.mn: http://legalinfo.mn/law/details/11192?lawid=11192

[2] www.mse.mn. (2017, 01 24). Retrieved 01 24, 2017, from Mongolian Stock Exchange: http://mse.mn/content/list/1/0

[3] Ablanedo-Rosas, J. H., Hongman, G., Xiaochuan, Z., Bahram, A., \& Haibo, W. (2010). A study of the relative efficiency of Chinese ports: a financial ratio-based data envelopment analysis approach. The Journal of Knowledge Engineering, 349-360.

[4] Amal, Y. A., Sameer, A. A., \& Yahya, Z. A.-S. (2012). Factors Affecting the Financial Performance of Jordanian Insurance Companies Listed at Amman Stock Exchange. Journal of Management Research, 266-289.

[5] Baltagi, B. H. (2005). Econometric Analysis of Panel Data. Great Britain: Antony Rowe Ltd.

[6] Daraio, \& Simar, L. (2007). Advanced Robust and Nonparametric Methods in Efficiency Analysis. Springer.

[7] Fenyves, V., Tibor, T., \& Kinga, Z. (2015). Financial Performance Evaluation of agricultural enterprises with DEA Method. elsevier, 423-431.

[8] George, E. H., \& Nickolaos , G. T. (2011). Industry performance evaluation with the use of financial ratios: An application of bootstrapped DEA. Elsevier, 5872-5880.

[9] Hollingsworth, \& P, S. (2003). Use of Ratios in data envelopment analysis. Applied economics letters, 733-735. 
[10] Hornungova, J., \& Frantisek, M. (2016). Financial performance evaluation of the Czech agricultural companies with factor analysis. Scientific Papers of the University of Pardubice. Series D, Faculty of Economics \& Administration, 26-37.

[11] HSIOA, C. (2003). Analysis of Panel Data. New York: Cambridge University Press.

[12] Kopp, R. J. (1981). The Measurement of Productive Efficiency: A Reconsideration. The quarterly journal of economics, 477-503.

[13] Liu, S. T. (2011). Performance measurement of Taiwan financial holding companies: An additive efficiency decomposition approach. Elsevier, 5674-5679.

[14] Luo, X. (2001). Evaluating the profitability and marketability efficiency of large banks an application of data envelopment analysis. Journal of Business Research, 627-635.

[15] Otto, L., \& Peter Bogetoft. (2011). Benchmarking with DEA, SFA, and R. New York: Springer Science Business Media, LLC.

[16] Vincova, K. (2005). Using DEA models to measure efficiency. BIATEC, 24-28.

[17] Yu, H. C. (1994). Financial efficiency analysis: a DEA approach. Financial efficiency analysis: a DEA approach. Beijing, People Republic of China. 